\section{Sociocultural pressure: a model of body dissatisfaction for young women}

\author{
Pressão sociocultural: um modelo de insatisfação \\ corporal para mulheres jovens
}

\author{
Presión sociocultural: un modelo de \\ insatisfacción corporal para mujeres jóvenes
}

\author{
Wanderson Roberto da Silva 1 \\ Júlia Valério Barra 1 \\ Angela Nogueira Neves 2 \\ João Marôco 3 \\ Juliana Alvares Duarte Bonini Campos 1
}

doi: 10.1590/0102-311X00059220

\begin{abstract}
The aim of the study was to verify the influence of pressure from sociocultural agents on dissatisfaction with face and body in young women mediated by the internalization of the lean and muscular body and to identify the contribution of individual characteristics to this model. A total of 612 university female students participated of study. The students completed the Portuguese versions of the Sociocultural Attitudes Towards Appearance Questionnaire-4

\author{
Correspondence \\ J. A. D. B. Campos \\ Universidade Estadual Paulista. \\ Rod. Araraquara-Jaú, Araraquara, SP 14800-903, Brasil. \\ juliana.campos@unesp.br \\ 1 Universidade Estadual Paulista, Araraquara, Brasil. \\ 2 Escola de Educação Física do Exército, Rio de Janeiro, Brasil. \\ 3 Instituto Universitário de Ciências Psicológicas, Sociais e da
}

Vida, Lisboa, Portugal.
\end{abstract} and of the Body Area Scale-Revised and a sociodemographic questionnaire. A hypothetical model was constructed using structural equation modeling to test the relationship between the variables. The model fit and the significance of the hypothetical paths were verified. The results provide evidence that the greater the pressure of sociocultural agents and the internalization of the lean body, the more women were dissatisfied with body and face appearance. The media contributed to a greater internalization of the muscular body, which reduced the body dissatisfaction. The practice of physical activity and a higher economic level contributed to a greater internalization of the muscular body, which reduced body dissatisfaction. A higher economic level also influenced the internalization of the lean body and increased the dissatisfaction with face and body. A higher body mass index contributed to a greater pressure from sociocultural agents, greater internalization of the lean body, and greater dissatisfaction with body and face. The relationships identified in the model can contribute to the development of strategies aimed at reducing body dissatisfaction and eating disorders in the population, such as body acceptance.

Body Image; Body Dissatisfaction; Women 


\section{Introduction}

Despite the recent efforts of health professionals, of researchers and of the media to promote a positive body image perception 1,2,3,4, body dissatisfaction rates are still high, especially among women 5,6,7, adolescents and young adults 8 . In a longitudinal study, Rohde et al. 9 report that body dissatisfaction is greater in adolescence and early adulthood, since in these phases, individuals gain autonomy, develop higher expectations and undergo social role readjustment 10.

Body dissatisfaction can be defined as a negative attitude towards physical appearance resulting from the discrepancy between one's body perceptions and the perceived ideal body 11. For decades, a thin body pattern was considered as ideal for women and a muscular one for men. Currently, both sexes aim for a body type with low fat and well-defined musculature, which is difficult to achieve and this has contributed to an increase in body dissatisfaction rates in the population 12,13,14. However, there are still significant rates of body dissatisfaction related to thinness among women, especially in Western countries 15 .

The state of continuous body dissatisfaction can cause profound distress leading to a stressful and inhibitory mental condition that surpasses that of the original cause. Negative conclusions about one's body can contribute to the development of self-destructive behaviors to achieve an appropriate image and be better accepted by a social group 16 . Among these behaviors, the alteration of food consumption stands out as it can trigger eating disorders and lead to conditions of low self-esteem, anxiety and depression 17,18,19,20.

Thus, understanding the factors that influence the definition of ideal body patterns and affect individual attitudes is relevant, and the sociocultural perspective is perhaps the most adequate theoretical basis for this analysis $15,18,21,22,23,24$. The assumption is that culture determines the ideal body pattern, which in turn is valued by members of the social circle (especially family, peers and the media) with great influence on body dissatisfaction and eating behavior, mediated by the internalization of the lean and athletic body ideals and social comparison 14,25.

Social comparison is contrasting one's body characteristics with those of others from the same environment and with the standards established by society/culture 26 . Downward social comparisons are made from a higher to a lower standard, usually promoting positive feelings towards the body. On the other hand, upward comparisons can lead to negative experiences, such as body dissatisfaction, anxiety, depression and general feeling of inadequacy $21,27,28$.

Internalization is the cognitive incorporation of values that involves the modification of thoughts and behaviors to reach the ideal body, based on a personal standard of physical attractiveness and beauty that the individual adopts as appropriate 13,14 . Currently, the two body types most commonly internalized are the "athletic" and "lean" 20,25. The athletic type is the body with muscle definition, while the lean type is a long and low-fat body $29,30,31$. The internalization of these body patterns has a direct effect on body dissatisfaction 5,25, which can contribute to negative results in vulnerable populations, such as young women. In Brazil, people strongly value the appearance of the body, and this has become a common aspect, especially among girls 32,33 . However, adults can also be concerned with body aesthetics $34,35,36$, which has contributed to the increase in body dissatisfaction rates in the population.

Still, individual factors can influence body dissatisfaction, which explains the variability of reactions observed in populations under the same cultural values and social pressures 19,24. For example, the practice of physical activity might have both a negative 37,38 and positive 39,40 relationship with body dissatisfaction. Other studies 15,22,41,42,43 emphasize that individuals with a higher body mass index, higher economic level and those who are younger can present greater body dissatisfaction and consequently develop depressive and binge-eating symptoms. In this way, understanding the factors that can influence people's body perception and promote the internalization of specific body patterns (e.g., lean and muscular) is important. Generally, Brazilian studies evaluate these concepts separately and a more complete investigation would be useful to help prepare health professionals to develop preventive protocols aimed at psychoeducation, thus contributing to the clinical management of individuals vulnerable to aesthetic issues. In addition, it can provide support for the development of public policies aimed at valuing a realistic and healthy body in order to prevent the development of eating disorders due to body image dissatisfaction. 
Thus, this study aimed at testing a hypothetical model to verify the relationship between pressure from sociocultural agents (family, peers and media), internalization of the lean body and the muscular body, and body dissatisfaction among young women, taking into account individual variables (body mass index - BMI, economic level, age and physical activity).

\section{Methods}

\section{Study design and sampling method}

This was a cross-sectional observational study, with a non-probabilistic sample design. Female students aged 18 to 30 years enrolled in a public university in the State of São Paulo, Brazil, were invited to participate. Students who agreed with and signed the Free and Informed Consent Term were included in the study.

The minimum sample size was estimated using the recommendation of 5 to 10 subjects per parameter of the tested model ${ }^{44}$ plus a number to compensate for losses (common in cross-sectional studies). Considering 93 parameters and a loss rate of $20 \%$, the minimum sample size was estimated to be from 582 to 1,163 subjects. A total of 769 students agreed to participate in the study, however 157 (20.4\%) did not respond to all items of the questionnaires and were excluded. Thus, the final sample was composed of 612 individuals, and this estimate was adequate to perform the analyses.

\section{Study variables and measures}

Information on age, economic level, BMI and physical activity (yes or no) were collected. The economic level of the participants was defined by social classes (A, B1, B2, C1, C2, D and E) using the 2019 Brazilian Economic Classification Criterion (Associação Brasileira de Empresas de Pesquisa. http:// www.abep.org/, accessed on Mar/2020). The BMI was calculated from the reported weight and height measures based on which the participants' anthropometric nutritional status was defined 45 .

Social pressure agents (family, peers and media) and the level of internalization of a muscular/ athletic or lean/low-fat body were estimated using the Sociocultural Attitudes Toward Appearance Questionnaire (SATAQ-4). Body dissatisfaction was estimated by the Body Area Scale-Revised (BAS-R).

SATAQ-4 was developed in English by Schaefer et al. 31 with 22 items distributed in five factors (Internalization of lean/low-fat body: items 3, 4, 5, 8 and 9; Internalization of muscular/athletic body: items 1, 2, 6, 7 and 10; Pressure from family: items 11, 12, 13 and 14; Pressure from peers: items 15, 16, 17 and 18; and Pressure from the media: items 19, 20, 21 and 22). Responses are provided in a Likert-type scale ranging from one (definitely disagree) to five (definitely agree). The Portuguese version of SATAQ- 4 applied in this study was proposed by Barra et al. 46 . Adequate fit and good reliability of the SATAQ-4 factorial model was verified in our sample [chi-square by degrees of freedom ratio $\left(\chi^{2} / \mathrm{df}\right)=5.10$, Comparative Fit Index $(\mathrm{CFI})=0.98$, Tucker-Lewis Index $(\mathrm{TLI})=0.98$, Root Mean Square Error of Approximation (RMSEA) $=0.08$, composite reliability $(\mathrm{CR})=0.90-0.97$ and alpha coefficient $(\alpha)=0.89-0.9746$.

BAS was originally proposed in English by Lerner et al. 47 with 24 items referring to body parts and general appearance in a single-factor model. Responses are also in a Likert-type scale ranging from one (very satisfied) to five (very dissatisfied). The Portuguese version of BAS was presented by Conti et al. ${ }^{48}$. Regarding the psychometric adequacy of the BAS for Brazilian adults, we conducted a previous study and identified that a two-factor model composed of 19 items (BAS-R: Dissatisfaction with face appearance: items 1, 2, 6, 15, 16, 17, 18, 19, 20 and 22; Dissatisfaction with body appearance: items $3,4,9,10,12,13,14,21$ and 23) was adequate 49 . For the sample of the present study, the BAS-R showed acceptable factorial validity $\left(\chi^{2} / \mathrm{df}=6.99, \mathrm{CFI}=0.92, \mathrm{TLI}=0.91, \mathrm{RMSEA}=0.09\right)$ and good reliability $(\mathrm{CR}=0.92-0.92, \alpha=0.92-0.92)$. 


\section{Ethical aspects}

Data collection took place in the classroom during a pre-established schedule with authorization from the class professor. All information was self-reported by students who voluntarily agreed to participate in the study without any compensation. The research was approved by the Human Research Ethics Committee of the School of Pharmaceutical Sciences at São Paulo State University (UNESP; CAAE: 63553516.4.0000.5426). All participants of the study gave consent by signing the Free Informed Consent form.

\section{Structural model}

To estimate the relationship between social pressure agents (family, peers and media), internalization of the lean and muscular body, dissatisfaction with body and face appearance, and explanatory variables (i.e., sample characteristics), a model was developed using structural equation modeling. The hypothetical paths were tested in two stages. In the first stage, hypothetical paths were tested according to the theoretical principles of the Tripartite Model by Thompson et al. 14. Internalizations of the lean and muscular body types were considered mediators between social pressure agents and dissatisfaction with body and face appearance (Figure 1a).

In the second stage, the variables age (continuous), BMI (continuous), economic level (categorical: $\mathrm{D}-\mathrm{E}=1, \mathrm{C} 1-\mathrm{C} 2=2, \mathrm{~B} 1-\mathrm{B} 2=3, \mathrm{~A}=4$ ), and physical activity practice (categorical: no = 0, yes $=1$ ) were added to the model to verify their relationship with latent variables (Figure $2 \mathrm{a}$ ).

To assess the models, goodness-of-fit criteria were first analyzed according to the indices $\chi^{2} / \mathrm{df} \leq$ 2.00 , CFI and TLI $\geq 0.90$, and RMSEA $\leq 0.1050$. Then, the paths were evaluated and only the significant ones $(\mathrm{p} \leq 0.05)$ were maintained in the model 50 . The analyses were performed using the MPlus 7.2 program (https://www.statmodel.com/).

\section{Results}

The students' average age was 20.85 (standard deviation [SD] = 2.33] years and the average BMI was $22.82 \mathrm{~kg} / \mathrm{m}^{2}$ (SD $\left.=3.98\right) .10 \%$ of students were classified as underweight, $64.7 \%$ as normal weight, $19.1 \%$ as overweight and $5.9 \%$ as obese. The sample distribution according to economic level was $22.1 \%$ in A (estimated average family income = BRL 25,554.33), 59.6\% in B1 (BRL 11,279.14) and B2 (BRL 5,641.64), 18\% in C1 (BRL 3,085.48) and C2 (BRL 1,748.59) and 0.3\% in D and E (BRL 719.81). More than half (55.9\%) of the sample did not perform physical activity. The structural model estimates considering the first stage are shown in Table 1.

Family, peers and the media had a significant relationship with the internalization of lean/low-fat body, and the greater the pressure of these agents, the more the individual internalized the lean body type. On the other hand, only the greatest pressure from the media contributed significantly to the greater internalization of the muscular/athletic body. The internalization of the lean/low-fat body significantly influenced dissatisfaction with face and body appearance, while the internalization of the muscular/athletic body showed a significant path only for dissatisfaction with body appearance. These findings indicated that women who internalize the lean/low-fat body type are more dissatisfied with their general physical appearance. In contrast, women who internalize the muscular/athletic body type are less dissatisfied with their body appearance (Figure 1a and Table 1 - initial model). In this way, only the significant paths of the first stage were maintained (Figure 1b and Table 1 - fitted model $)$ and this model showed adequate goodness-of-fit criteria $\left(\chi^{2} / \mathrm{df}=2.57, \mathrm{CFI}=0.97\right.$, TLI $=0.97$, RMSEA $=0.05)$. Then, the explanatory variables were added in the fitted model and tested in the second stage. The estimates of the model considering the second stage are shown in Table 2.

Age was not significant for any of the factors evaluated. BMI was significant for all factors except for internalization of the lean/low-fat body type and dissatisfaction with face appearance. Women with a higher BMI felt more pressured by family, peers and the media to change their bodies, which contributed indirectly to a greater internalization of the lean body type and directly to a greater dissatisfaction with body appearance. Furthermore, students with lower BMI internalized more the 
Figure 1

Representation of the hypothetical models for first stage showing the tested paths.

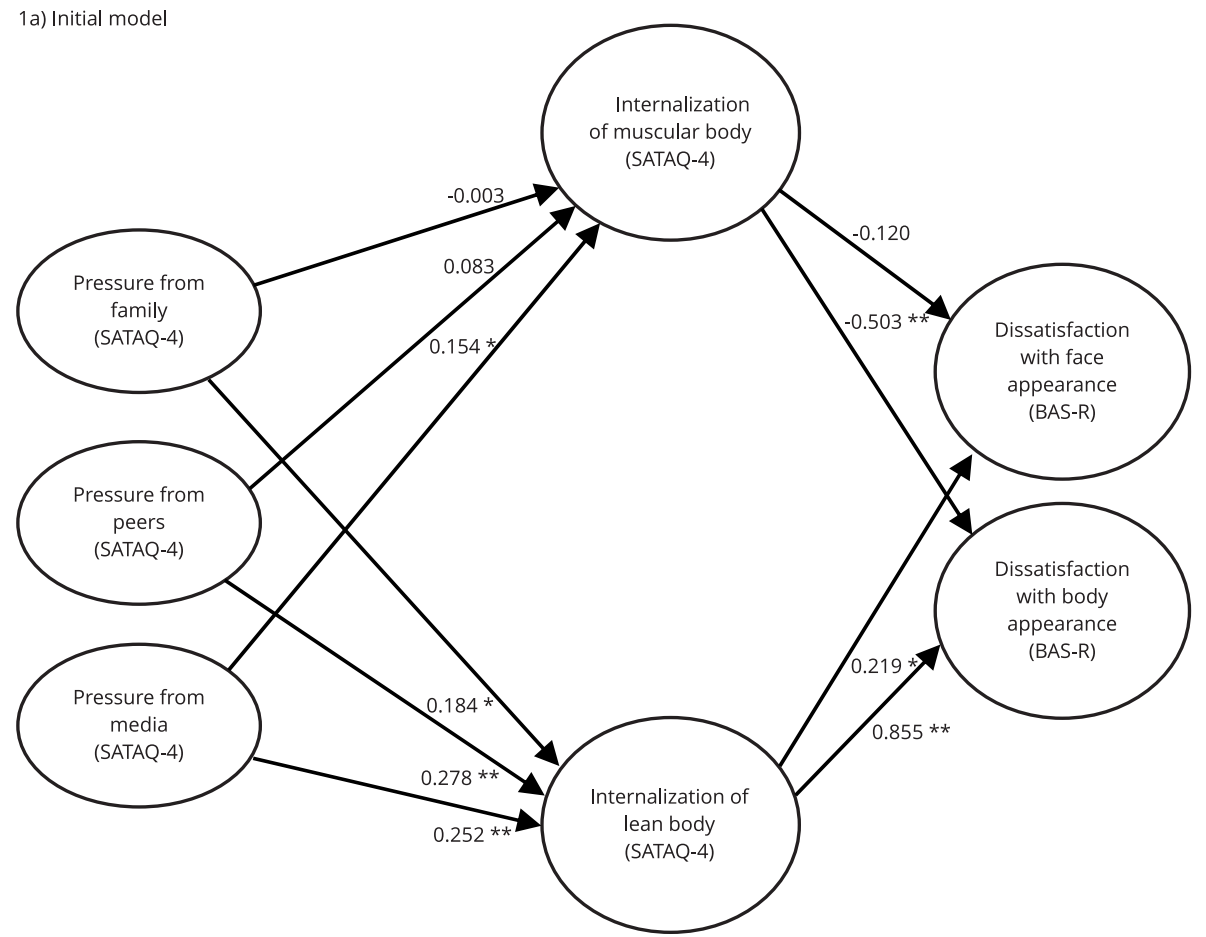

1b) Fitted model (only with significant variables)

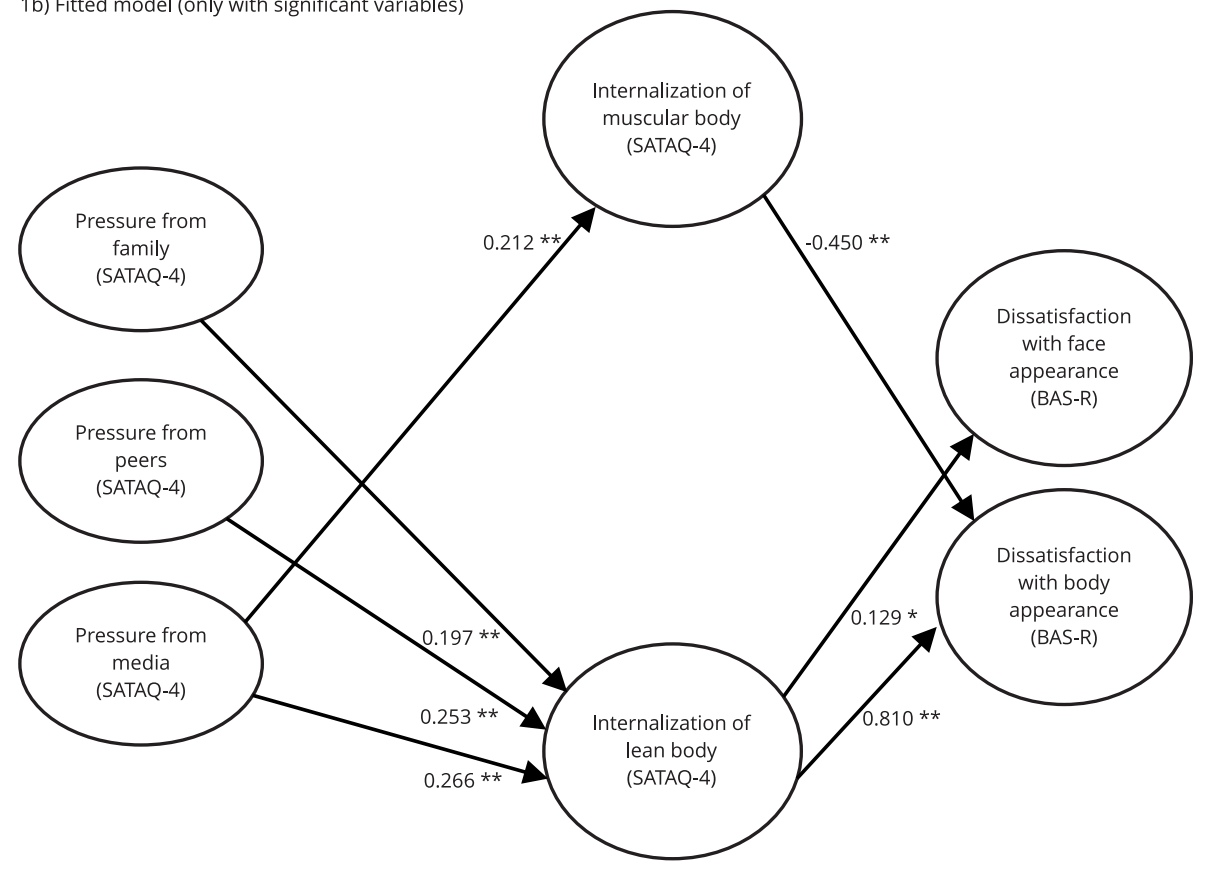

BAS-R: Body Area Scale-Revised; SATAQ-4: Sociocultural Attitudes TowardAppearance Questionnaire-4.

Note: values: $\beta$ standardized estimate.

* $\mathrm{p}<0.05$;

** $p<0.001$. 
Figure 2

Representation of the hypothetical models for second stage showing the tested paths.

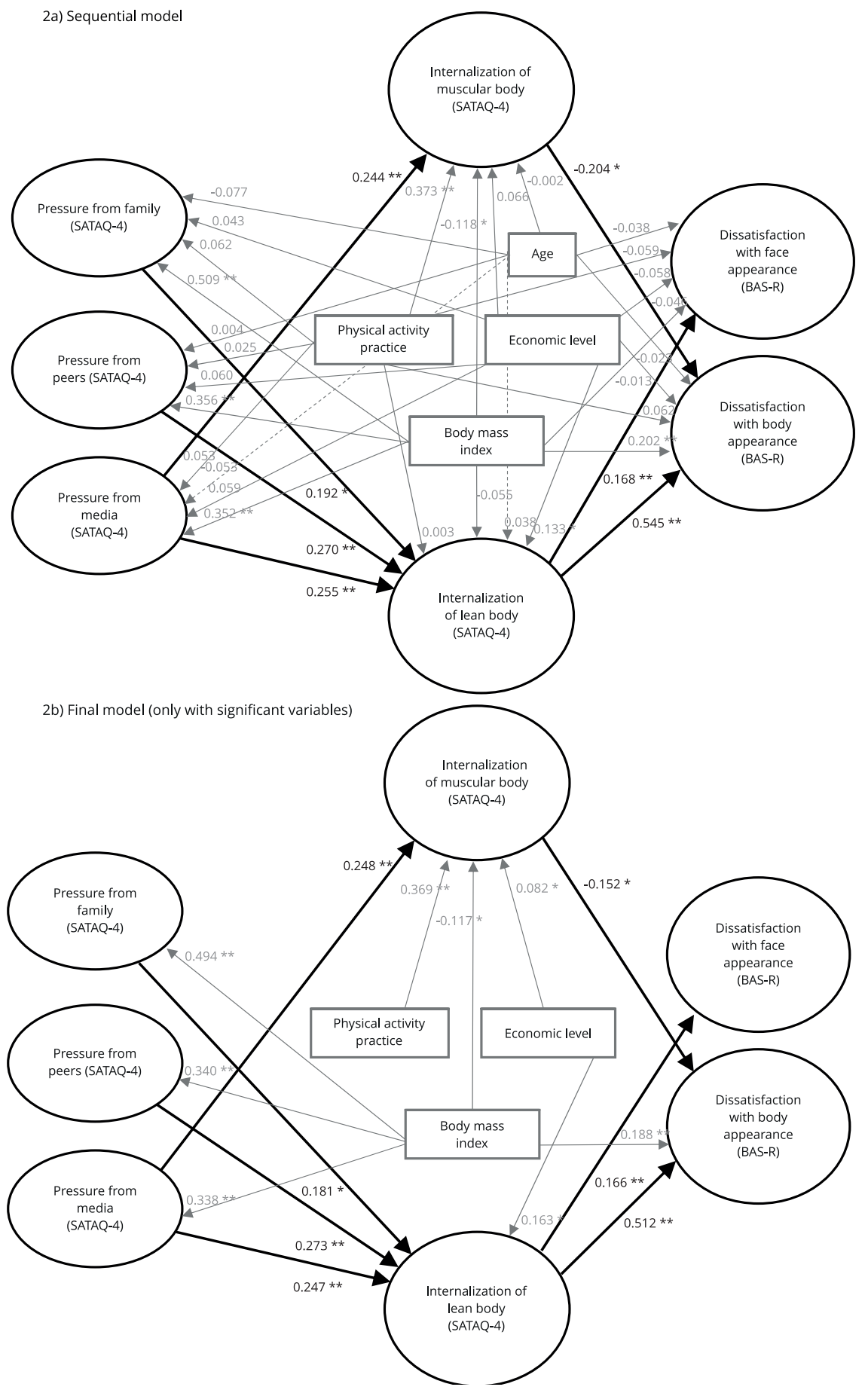

BAS-R: Body Area Scale-Revised; SATAQ-4: Sociocultural Attitudes Toward Appearance Questionnaire-4.

Note: latent variables are represented by circles (black lines) and manifest variables are represented by rectangles (gray lines). The dotted lines are direct paths from the age variable. Values: $\beta$ standardized estimate.

$* p<0.05$;

** $p<0.001$. 
Table 1

First stage testing of the structural model in the sample of university female students.

\begin{tabular}{|c|c|c|c|c|c|c|}
\hline \multirow[t]{2}{*}{ Independent variable $\rightarrow$ Dependent variable } & \multicolumn{3}{|c|}{ Initial model } & \multicolumn{3}{|c|}{ Fitted model } \\
\hline & $\beta$ & SE & p-value & $\beta$ & SE & p-value \\
\hline Pressure from family $\rightarrow$ Internalization of lean body & 0.184 & 0.056 & 0.004 * & 0.197 & 0.048 & $<0.001 *$ \\
\hline Pressure from family $\rightarrow$ Internalization of muscular body & -0.003 & 0.054 & 0.966 & - & - & - \\
\hline Pressure from peers $\rightarrow$ Internalization of lean fat body & 0.278 & 0.059 & $<0.001 *$ & 0.253 & 0.054 & $<0.001 *$ \\
\hline Pressure from peers $\rightarrow$ Internalization of muscular body & 0.083 & 0.055 & 0.243 & - & - & - \\
\hline Pressure from media $\rightarrow$ Internalization of lean body & 0.252 & 0.043 & $<0.001 *$ & 0.266 & 0.042 & $<0.001 *$ \\
\hline Pressure from media $\rightarrow$ Internalization of muscular body & 0.154 & 0.041 & $0.010 *$ & 0.212 & 0.032 & $<0.001 *$ \\
\hline Internalization of muscular body $\rightarrow$ Dissatisfaction with face appearance & -0.120 & 0.100 & 0.147 & - & - & - \\
\hline Internalization of muscular body $\rightarrow$ Dissatisfaction with body appearance & -0.503 & 0.096 & $<0.001 *$ & -0.450 & 0.080 & $<0.001 *$ \\
\hline Internalization of lean body $\rightarrow$ Dissatisfaction with face appearance & 0.219 & 0.079 & $0.005 *$ & 0.129 & 0.043 & $0.003 *$ \\
\hline Internalization of lean body $\rightarrow$ Dissatisfaction with body appearance & 0.855 & 0.081 & $<0.001 *$ & 0.810 & 0.071 & $<0.001$ * \\
\hline
\end{tabular}

$\beta$ : standardized estimate; SE: standard error.

Note: pressure from family, peers, and media and internalization of muscular and lean body were evaluated by the Sociocultural Attitudes Toward Appearance Questionnaire-4. Dissatisfaction with face and body appearance were evaluated by the Body Area Scale-Revised. $* \mathrm{p}<0.05$.

muscular/athletic body. The practice of physical activity was significant only for the internalization of the muscular/athletic body. Women who practiced more physical activity were the ones who most internalized the muscular body type. The economic level was a significant factor for internalization of the muscular/athletic body and for internalization of the lean/low-fat body. These results showed that women with greater economic power internalized more the muscular and lean body (Figure 2a and Table 2 - sequential model). The final model (Figure $2 \mathrm{~b}$ and Table 2 - final model) only with the significant paths showed adequate goodness-of-fit criteria $\left(\chi^{2} / \mathrm{df}=2.17\right.$, CFI $=0.97$, TLI $=0.97$, RMSEA = 0.04).

\section{Discussion}

Significant relationships were found between agents of social pressure, internalization of the muscular and lean body, practice of physical activity, BMI, economic level and body dissatisfaction. The findings contribute to the development of preventive and educational actions (e.g., encourage a healthy lifestyle that includes moderate exercise, nutritious eating and body acceptance) aimed at raising awareness and approaching individuals with body dissatisfaction. Specific characteristics that were identified, such as eating restriction, excessive physical activity and social isolation, must be carefully considered in order to reduce risky behaviors that can affect physical and mental health of people.

In the first stage of analysis we found that young women internalize the lean and low-fat body, most likely because of the pressure from family, peers and the media towards having an ideal body pattern. This corroborates the theory of the Tripartite Model, in which social pressure agents propagate the internalization of the ideal body according to the local culture. Previous studies $31,43,51,52,53,54$ have confirmed this relationship between sociocultural factors and body image. In the Brazilian context, Carvalho et al. 35 reported that only pressures from the family and the media had a significant relationship with the internalization of the ideal body in adult women. However, the authors used SATAQ-3 55, which assesses the internalization of the athletic body and influence from the media, without considering interpersonal pressures. This may have contributed to the divergence of results with our study. 
Table 2

Second stage testing of the structural model in the sample of university female students.

\begin{tabular}{|c|c|c|c|c|c|c|}
\hline \multirow[t]{2}{*}{ Independent variable $\rightarrow$ Dependent variable } & \multicolumn{3}{|c|}{ Sequential model } & \multicolumn{3}{|c|}{ Final model } \\
\hline & $\beta$ & SE & p-value & $\beta$ & SE & p-value \\
\hline Pressure from family $\rightarrow$ Internalization of lean body & 0.192 & 0.053 & $0.003 *$ & 0.181 & 0.052 & 0.004 * \\
\hline Pressure from peers $\rightarrow$ Internalization of lean body & 0.270 & 0.062 & $<0.001$ * & 0.273 & 0.064 & $<0.001$ * \\
\hline Pressure from media $\rightarrow$ Internalization of lean body & 0.255 & 0.045 & $<0.001 *$ & 0.247 & 0.046 & $<0.001$ * \\
\hline Pressure from media $\rightarrow$ Internalization of muscular body & 0.244 & 0.031 & $<0.001$ * & 0.248 & 0.031 & $<0.001$ * \\
\hline Internalization of muscular body $\rightarrow$ Dissatisfaction with body appearance & -0.204 & 0.067 & $<0.001 *$ & -0.152 & 0.057 & 0.004 * \\
\hline Internalization of lean body $\rightarrow$ Dissatisfaction with face appearance & 0.168 & 0.043 & $<0.001$ * & 0.166 & 0.043 & $<0.001$ * \\
\hline Internalization of lean body $\rightarrow$ Dissatisfaction with body appearance & 0.545 & 0.057 & $<0.001$ * & 0.512 & 0.052 & $<0.001$ * \\
\hline Age $\rightarrow$ Pressure from Family & -0.077 & 0.017 & 0.052 & - & - & - \\
\hline Age $\rightarrow$ Pressure from peers & 0.004 & 0.016 & 0.924 & - & - & - \\
\hline Age $\rightarrow$ Pressure from media & -0.053 & 0.017 & 0.192 & - & - & - \\
\hline Age $\rightarrow$ Internalization of lean body & 0.038 & 0.014 & 0.339 & - & - & - \\
\hline Age $\rightarrow$ Internalization of muscular body & -0.002 & 0.012 & 0.963 & - & - & - \\
\hline Age $\rightarrow$ Dissatisfaction with facial appearance & -0.038 & 0.015 & 0.398 & - & - & - \\
\hline Age $\rightarrow$ Dissatisfaction with body appearance & -0.046 & 0.012 & 0.220 & - & - & - \\
\hline $\mathrm{BMI} \rightarrow$ Pressure from family & 0.509 & 0.010 & $<0.001 *$ & 0.494 & 0.010 & $<0.001$ * \\
\hline $\mathrm{BMI} \rightarrow$ Pressure from peers & 0.356 & 0.009 & $<0.001$ * & 0.340 & 0.009 & $<0.001$ * \\
\hline $\mathrm{BMI} \rightarrow$ Pressure from media & 0.352 & 0.010 & $<0.001 *$ & 0.338 & 0.010 & $<0.001$ * \\
\hline $\mathrm{BMI} \rightarrow$ Internalization of lean body & -0.055 & 0.009 & 0.220 & - & - & - \\
\hline $\mathrm{BMI} \rightarrow$ Internalization of muscular body & -0.118 & 0.008 & 0.006 * & -0.117 & 0.007 & 0.005 * \\
\hline $\mathrm{BMI} \rightarrow$ Dissatisfaction with face appearance & -0.058 & 0.009 & 0.183 & - & - & - \\
\hline $\mathrm{BMI} \rightarrow$ Dissatisfaction with body appearance & 0.202 & 0.007 & $<0.001$ * & 0.188 & 0.007 & $<0.001$ * \\
\hline Economic level $\rightarrow$ Pressure from family & 0.043 & 0.060 & 0.273 & - & - & - \\
\hline Economic level $\rightarrow$ Pressure from peers & 0.060 & 0.059 & 0.185 & - & - & - \\
\hline Economic level $\rightarrow$ Pressure from media & 0.059 & 0.064 & 0.146 & - & - & - \\
\hline Economic level $\rightarrow$ Internalization of lean body & 0.133 & 0.050 & 0.001 * & 0.163 & 0.059 & $<0.001$ * \\
\hline Economic level $\rightarrow$ Internalization of muscular body & 0.066 & 0.043 & 0.094 & 0.082 & 0.044 & 0.040 * \\
\hline Economic level $\rightarrow$ Dissatisfaction with face appearance & -0.023 & 0.053 & 0.600 & - & - & - \\
\hline Economic level $\rightarrow$ Dissatisfaction with body appearance & -0.013 & 0.047 & 0.740 & - & - & - \\
\hline Physical activity practice $\rightarrow$ Pressure from family & 0.062 & 0.077 & 0.111 & - & - & - \\
\hline Physical activity practice $\rightarrow$ Pressure from peers & 0.025 & 0.076 & 0.575 & - & - & - \\
\hline Practice of physical activity $\rightarrow$ Pressure from media & 0.053 & 0.083 & 0.196 & - & - & - \\
\hline Practice of physical activity $\rightarrow$ Internalization of lean body & 0.003 & 0.066 & 0.932 & - & - & - \\
\hline Physical activity practice $\rightarrow$ Internalization of the muscular body & 0.373 & 0.063 & $<0.001 *$ & 0.369 & 0.061 & $<0.001$ * \\
\hline Practice of physical activity $\rightarrow$ Dissatisfaction with face appearance & -0.059 & 0.068 & 0.177 & - & - & - \\
\hline Physical activity practice $\rightarrow$ Dissatisfaction with body appearance & 0.062 & 0.070 & 0.184 & - & - & - \\
\hline
\end{tabular}

$\beta$ : standardized estimate; BMI: body mass index; SE: standard error.

Note: pressure from family, peers, and media and internalization of muscular and lean body were evaluated by the Sociocultural Attitudes Toward Appearance Questionnaire-4. Dissatisfaction with face and body appearance were evaluated by the Body Area Scale-Revised . Sequential model = only significant paths of the first stage and the manifest variables

$* p<0.05$. 
Only pressure from the media was a significant factor for the internalization of the muscular body. The media is the main means of spreading information about the ideal body, which focuses in thinness and muscle definition for women 23,31,54. The internalization of the muscular/athletic body was inversely related to women's dissatisfaction with body appearance, that is, the greater the internalization, the lower the body dissatisfaction. On the other hand, the greater the internalization of the lean/ low-fat body, the greater the body dissatisfaction. Based on Sturman et al. 30 women in general have a misperception of body fat but not of their level of muscularity, suggesting that they attribute the athletic body to a healthy body. However, further studies are needed to support this finding, especially in the Brazilian context.

The direct relationship of the practice of physical activity on the internalization of the muscular/athletic body was also verified. The practice of physical activity is related to the feeling of being healthy, having high self-esteem and lower body dissatisfaction. Lepage \& Crowther 39 observed a lower body dissatisfaction in a sample of American female students who practiced physical activity at least three times a week. Tylka \& Homan 40 tested a model of intuitive eating and body appreciation in physically active American college women. The authors reported that practicing physical activity focusing on the health benefits contributed significantly to a higher body appreciation. Our results corroborate previous findings, highlighting the benefits of physical activity for body awareness. However, when excessive, exercising can become a disorder and have a negative effect on body image as pointed out by Tylka \& Homan 40 .

BMI had an inverse relationship with the internalization of the muscular/athletic body. On the other hand, pressure from family, peers and the media had a direct relationship with that variable, as well as with body dissatisfaction. These results corroborate the literature $43,54,56,57$, indicating a positive correlation between sociocultural pressures and BMI, that is, overweight and obese individuals may experience greater pressure from other people and the media to change their bodies. BMI had indirect associations with internalization of the lean/low-fat body depending on the perceived pressures and this finding corroborates the results of Moreno-Dominguez et al. 43. Therefore, in addition to BMI, these pressures should be taken into account in studies related to body dissatisfaction, corroborating the theories raised by Cash \& Smolak 58 that sociocultural influence is of great importance in the process of internalization and search for the ideal body.

Only the internalization of the lean/low-fat body type had a significant and direct association with facial dissatisfaction. This indicates that people internalize the body patterns differently that specific body parts within these patterns. Facial appearance is scarcely evaluated as an important part of body image investigation 59,60 . This makes direct comparison with the literature difficult, since body image measures focus more on the evaluation of other body characteristics, such as shape, weight, abdomen and legs 61 . Therefore, it is suggested that body internalizations be investigated separately from body parts when testing a theoretical model, so these relationships can be evaluated in a more thorough way.

Age was not a significant factor in any tested path, which may have occurred due to the low age variability within the sample. The way in which sociocultural pressures are perceived may differ according to the stages of human development 24 , but our study sample consisted only of young adults, which may have hindered age-related differences. Economic level, on the other hand, had a direct relationship on the internalizations of the athletic/muscular and lean/low-fat body types, revealing that women from higher economic level internalized more ideal body standards. To our knowledge, only Khalaf et al. 62 found similar results, and any statements on this finding would be mere speculation. Some researchers 63,64 suggest that people with greater economic power are more concerned with body aesthetics and may have greater body dissatisfaction; however, more studies are needed to elucidate the relationship among body internalization and economic level.

This study had some limitations. The cross-sectional study design does not allow the establishment of a temporal cause and effect relationship, despite helping to identify risk characteristics for promoting interventions. The use of a non-probabilistic sample, the possible biases due to data collection (loss rate $=20 \%$ ) and the use of a specific factorial structure for BAS-R limits the generalizability of the results for other populations than adult college women. Still as a limitation, it is worth mentioning that age, physical activity, socioeconomic level and BMI can be interdependent rather than independent variables and this should be considered in future protocols. Despite these limita- 
tions, this study separately assessed body internalizations and body dissatisfaction, which provided data that are more detailed than that of previous studies. In addition, the insertion of demographic and anthropometric characteristics in the model can help identify the most vulnerable profiles for body dissatisfaction.

\section{Conclusion}

Social pressure from family, peers and media had a direct and significant association with the internalization of the lean/low-fat body, leading to greater dissatisfaction with the body and facial appearance. Pressure from the media, higher economic level and the practice of physical activity influenced the internalization of the muscular/athletic body, which in turn was inversely associated with body dissatisfaction. BMI was directly associated with body dissatisfaction and how sociocultural pressures are perceived, and inversely associated with the internalization of the muscular/athletic body. Such findings can contribute with epidemiological screening for the development of preventive and educational actions aimed at people vulnerable to eating disorders and body dysmorphia.

\section{Contributors}

W. R. Silva participated in the design and theoretical development of the study and in the writing and revision of the manuscript sent for publication. J. V. Barra participated in the theoretical development of the study, data collection and analysis, and in the writing of the manuscript sent for publication. A. $\mathrm{N}$. Neves and J. Marôco contributed in the design of the study and in the review of the manuscript sent for publication. J. A. D. B. Campos participated in the design and theoretical development of the study and in the review of the manuscript sent for publication.

\section{Additional informations}

ORCID: Wanderson Roberto da Silva (0000-00018897-8772); Júlia Valério Barra (0000-0002-85539691); Angela Nogueira Neves (0000-0001-83041040); João Marôco (0000-0001-9214-5378); Juliana Alvares Duarte Bonini Campos (0000-00017123-5585).

\section{Acknowlegdments}

The authors thank the São Paulo State Research Foundation (FAPESP; 2017/18679-0), the Brazilian Graduate Studies Coordinating Board (CAPES; financing code 001), and the Brazilian National Research Council (CNPq; 131073/2017-6) for financial support.

\section{References}

1. Hopkins E, Lee AH. Formative research for UCLA EATask force's body image social marketing campaign. http://citeseerx.ist.psu.edu/ viewdoc/download? doi=10.1.1.475.4748\&rep =rep1\&type =pdf (accessed on Mar/2020).

2. Mulgrew KE, McCulloch K, Farren E, Prichard I, Lim MSC. This girl can \#jointhemovement: effectiveness of physical functionality-focused campaigns for women's body satisfaction and exercise intent. Body Image 2018; 24:26-35.

3. Convertino AD, Rodgers RF, Franko DL, Jodoin A. An evaluation of the Aerie Real campaign: potential for promoting positive body image? J Health Psychol 2019; 24:726-37.

4. Rodgers RF, Kruger L, Lowy AS, Long S, Richard C. Getting real about body image: a qualitative investigation of the usefulness of the Aerie Real campaign. Body Image 2019; 30:12734.

5. Girard M, Rodgers RF, Chabrol H. Prospective predictors of body dissatisfaction, drive for thinness, and muscularity concerns among young women in France: a sociocultural model. Body Image 2018; 26:103-10.

6. Fardouly J, Willburger BK, Vartanian LR. Instagram use and young women's body image concerns and self-objectification: testing mediational pathways. New Media Soc 2018; 20:1380-95.

7. Mulgrew KE, Tiggemann M. Form or function: does focusing on body functionality protect women from body dissatisfaction when viewing media images? J Health Psychol 2018; 23:84-94. 
8. Hardit SK, Hannum JW. Attachment, the tripartite influence model, and the development of body dissatisfaction. Body Image 2012; 9:469-75.

9. Rohde P, Stice E, Marti CN. Development and predictive effects of eating disorder risk factors during adolescence: implications for prevention efforts. Int J Eat Disord 2015; 48:18798.

10. Grossbard JR, Neighbors C, Larimer ME. Perceived norms for thinness and muscularity among college students: what do men and women really want? Eat Behav 2011; 12:192-9.

11. Heider N, Spruyt A, De Houwer J. Body dissatisfaction revisited: on the importance of implicit beliefs about actual and ideal body image. Psychol Belg 2018; 58:158-73.

12. Benton C, Karazsia BT. The effect of thin and muscular images on women's body satisfaction. Body Image 2015; 13:22-7.

13. Grogan S. Body image: understanding body dissatisfaction in men, women and children. New York: Routledge; 2016.

14. Thompson JK, Heinberg LJ, Altabe M, Tantleff-Dunn S. Exacting beauty: theory, assessment, and treatment of body image disturbance. Washington DC: American Psychological Association; 1999.

15. Swami V. Cultural influences on body size ideals: unpacking the impact of Westernization and modernization. Eur Psychol 2015; 20:4451.

16. Rosen JC, Orosan P, Reiter J. Cognitive behavior therapy form negative body image in obese women. Behavior Therapy 1995; 26:25-42.

17. Thompson JK, Stice E. Thin-ideal internalization: mounting evidence for a new risk factor for body-image disturbance and eating pathology. Curr Dir Psychol Sci 2001; 10:181-3.

18. Cafri G, Yamamiya Y, Brannick M, Thompson JK. The influence of sociocultural factors on body image: a meta-analysis. Clin Psychol 2005; 12:421-33.

19. Dakanalis A, Carra G, Calogero R, Fida R, Clerici M, Zanetti MA, et al. The developmental effects of media-ideal internalization and self-objectification processes on adolescents' negative body-feelings, dietary restraint, and binge eating. Eur Child Adolesc Psychiatry 2015; 24:997-1010.

20. Schaefer LM, Burke NL, Thompson JK. Thinideal internalization: how much is too much? Eat Weight Disord 2018; 24:933-7.

21. Tantleff-Dunn S, Lindner DM. Body image and social functioning. In: Cash TF, Pruzinsky T, editors. Body image: a handbook of science, practice, and prevention. New York: Guilford Press; 2011. p. 263-70.

22. Rakhkovskaya LM, Warren CS. Sociocultural and identity predictors of body dissatisfaction in ethnically diverse college women. Body Image 2016; 16:32-40.
23. Calogero RM, Boroughs M, Thompson JK. The impact of Western beauty ideals on the lives of women and men: a sociocultural perspective. In: Swami V, Furnham A, editors. Body beautiful: evolutionary and sociocultural perspectives. New York: Palgrave Macmillan; 2007. p. 259-98.

24. Tiggermann M. Sociocultural perspectives on human appearance and body image. In: Cash TF, Smolak L, editors. Body image. 2nd Ed. New York: The Guilford Press; 2012. p. 12-9.

25. Thompson JK, Schaefer LM, Menzel JE. Internalization of thin-ideal and muscular-ideal. In: Cash TF, editor. Encyclopedia of body image and human appearance. v. 2. San Diego: Elsevier Academic Press; 2012. p. 499-504.

26. Campana ANNB, Tavares MCGCF. Avaliação da imagem corporal: instrumentos e diretrizes para pesquisa. São Paulo: Phorte Editora; 2009.

27. Corson PN, Andersen A. Body image issues among boys and men. In: Cash TF, Pruzinsky T, editors. Body image: a handbook of theory, research and clinical practice. New York: Guilford Press; 2002. p. 192-9.

28. Festinger L. A theory of social comparison process. Human Relations 1954; 7:117-40.

29. Uhlmann LR, Donovan CL, Zimmer-Gembeck MJ, Bell HS, Ramme RA. The fit beauty ideal: a healthy alternative to thinness or a wolf in sheep's clothing? Body Image 2018; 25:23-30.

30. Sturman D, Stephen ID, Mond J, Stevenson RJ, Brooks KR. Independent aftereffects of fat and muscle: implications for neural encoding, body space representation, and body image disturbance. Sci Rep 2017; 7:40392.

31. Schaefer LM, Burke NL, Thompson JK, Dedrick RF, Heinberg LJ, Calogero RM, et al. Development and validation of the Sociocultural Attitudes Towards Appearance Questionnaire-4 (SATAQ-4). Psychol Assess 2015; 27:54-67.

32. Amaral ACS, Ferreira MEC. Body dissatisfaction and associated factors among Brazilian adolescents: a longitudinal study. Body Image 2017; 22:32-8.

33. Tebar WR, Canhin DS, Colognesi LA, Morano A, Silva DTC, Christofaro DGD. Body dissatisfaction and its association with domains of physical activity and of sedentary behavior in a sample of 15,632 adolescents. Int J Adolesc Med Health 2020; (Online ahead of print).

34. Silva DAS, Nahas MV, Sousa TF, Del Duca GF, Peres KG. Prevalence and associated factors with body image dissatisfaction among adults in southern Brazil: a population-based study. Body Image 2011; 8:427-31.

35. Carvalho PHB, Alvarenga MDS, Ferreira MEC. An etiological model of disordered eating behaviors among Brazilian women. Appetite $2017 ; 116: 164-72$. 
36. Florêncio RS, Oliveira ACA, Santiago JCS, Ribeiro DC, Almeida ILS, Pessoa VLMP, et al. Body and health perception for obesity in young adults. Int Arch Med 2020; 11:1-7.

37. Johnson F, Wardle J. Dietary restraint, body dissatisfaction, and psychological distress: a prospective analysis. J Abnorm Psychol 2005; 114:119-25.

38. Hausenblas H, Fallon EA. Exercise and body image: a meta-analysis. Psychol Health 2006; 21:33-47.

39. Lepage ML, Crowther JH. The effects of exercise on body satisfaction and affect. Body Image 2010; 7:124-30.

40. Tylka TL, Homan KJ. Exercise motives and positive body image in physically active college women and men: Exploring an expanded acceptance model of intuitive eating. Body Image 2015; 15:90-7.

41. MacNeill LP, Best LA, Davis LL. The role of personality in body image dissatisfaction and disordered eating: discrepancies between men and women. J Eat Disord 2017; 5:44.

42. van den Berg P, Neumark-Sztainer D. Fat'n happy 5 years later: is it bad for overweight girls to like their bodies? J Adolesc Health 2007; 14:415-7.

43. Moreno-Dominguez S, Rutsztein G, Geist TA, Pomichter EE, Cepeda-Benito A. Body mass index and nationality (Argentine vs. Spanish) moderate the relationship between internalization of the thin ideal and body dissatisfaction: a conditional mediation model. Front Psychol 2019; 10:582.

44. Hair Jr. JF, Black WC, Babin B, Anderson RE. Multivariate data analysis. 7 th Ed. Upper Saddle River: Prentice Hall; 2009.

45. World Health Organization. Obesity: preventing and managing the global epidemic. Geneva: World Health Organization; 2000. (Technical Report Series).

46. Barra JV, Silva WRD, Marôco J, Campos JADB. Adaptação transcultural e validação do Questionário de Atitudes Socioculturais em Relação à Aparência-4 (SATAQ-4) aplicado a estudantes universitários. Cad Saúde Pública 2019; 35:e00170218.

47. Lerner RM, Karabenick SA, Stuart JL. Relations among physical attractiveness, body attitudes, and self-concept in male and female college students. J Psychol 1973; 85:119-29.

48. Conti MA, Latorre MRDO, Hearst N, Segurado A. Cross-cultural adaptation, validation and reliability of the Body Area Scale for Brazilian adolescents. Cad Saúde Pública 2009; 25:2179. 86.

49. Barra JV. Impacto das atitudes socioculturais na insatisfação com a aparência geral do corpo de estudantes universitários. São Paulo: Universidade Estadual Paulista; 2019.

50. Marôco J. Análise de equações estruturais: fundamentos teóricos, software \& aplicações. 2a Ed. Lisboa: ReportNumber; 2014.
51. Rodgers R, Chabrol H, Paxton SJ. An exploration of the tripartite influence model of body dissatisfaction and disordered eating among Australian and French college women. Body Image 2011; 8:208-15.

52. Silva WRD, Marôco J, Campos J. Escala de Influência dos Três Fatores (TIS) aplicada a estudantes universitários: estudo de validação e aplicação. Cad Saúde Pública 2019; 35:e00179318.

53. Shagar PS, Donovan CL, Loxton N, Boddy J, Harris N. Is thin in everywhere?: a cross-cultural comparison of a subsection of Tripartite Influence Model in Australia and Malaysia. Appetite 2019; 134:59-68.

54. Stojcic I, Dong X, Ren X. Body image and sociocultural predictors of body image dissatisfaction in Croatian and Chinese women. Front Psychol 2020; 11:731.

55. Thompson JK, van den Berg $\mathrm{P}$, Roehrig $\mathrm{M}$, Guarda AS, Heinberg LJ. The sociocultural attitudes towards appearance scale-3 (SATAQ-3): development and validation. Int J Eat Disord 2004; 35:293-304.

56. van Den Berg P, Thompson JK, ObremskiBrandon K, Coovert M. The Tripartite Influence model of body image and eating disturbance: a covariance structure modeling investigation testing the mediational role of appearance comparison. J Psychosom Res 2002; 53:1007-20.

57. Jeffers AJ, Cotter EW, Snipes DJ, Benotsch EG. $\mathrm{BMI}$ and depressive symptoms: the role of media pressures. Eat Behav 2013; 14:468-71.

58. Cash TF, Smolak L. Body image: a handbook of theory, research, and clinical practice. $2^{\text {a }} \mathrm{Ed}$. New York: The Guilford Press; 2011.

59. Petrie TA, Tripp MM, Harvey P. Factorial and construct validity of the body parts satisfaction scale-revised: an examination of minority and nonminority women. Psychol Women Q 2002; 26:213-21.

60. Moody TD, Shen VW, Hutcheson NL, Henretty JR, Sheen CL, Strober M, et al. Appearance evaluation of others' faces and bodies in anorexia nervosa and body dysmorphic disorder. Int J Eat Disord 2017; 50:127-38.

61. Kling J, Kwakkenbos L, Diedrichs PC, Rumsey N, Frisen A, Brandão MP, et al. Systematic review of body image measures. Body Image 2019; 30:170-211.

62. Khalaf A, Westergren A, Berggren V, Ekblom O, Al-Hazzaa HM. Perceived and ideal body image in young women in South Western Saudi Arabia. J Obes 2015; 2015:697163.

63. Silva WRD, Santana MS, Marôco J, Maloa BFS, Campos J. Body weight concerns: crossnational study and identification of factors related to eating disorders. PLoS One 2017; 12:e0180125.

64. Maruf FA, Akinpelu AO, Udoji NV. Differential perceptions of body image and body weight among adults of different socioeconomic status in a sub-urban population. J Biosoc Sci 2014; 46:279-93. 


\section{Resumo}

O objetivo do estudo foi verificar a influência da pressão de agentes socioculturais na insatisfação com o rosto e o corpo em mulheres jovens mediada pela internalização do corpo magro e musculoso e identificar a contribuição das características individuais para esse modelo. Um total de 612 estudantes universitárias participaram do estudo. As alunas responderam às versões em português do Sociocultural Attitudes Towards Appearance Questionnaire-4 e da Body Area Scale-Revised e um questionário sociodemográfico. Um modelo hipotético foi construído usando modelagem de equações estruturais para testar a relação entre as variáveis. $O$ ajuste do modelo e a significância dos caminhos hipotéticos foram verificados. Os resultados fornecem evidências de que quanto maior a pressão dos agentes socioculturais e a internalização do corpo magro, mais as mulheres ficam insatisfeitas com a aparência corporal e facial. A mídia contribuiu para uma maior internalização do corpo muscular, o que diminuiu a insatisfação corporal. A prática de atividade física e um maior nível econômico contribuíram para uma maior internalização da musculatura corporal, o que reduziu a insatisfação corporal. Um nível econômico mais elevado também influenciou na internalização do corpo magro e aumentou a insatisfação com o rosto e o corpo. O maior índice de mass a corporal contribuiu para uma maior pressão dos agentes socioculturais, maior internalização do corpo magro e maior insatisfação com o corpo e a face. As relações identificadas no modelo podem contribuir para o desenvolvimento de estratégias que visem reduzir a insatisfação corporal e os transtornos alimentares na população, como a aceitação corporal.

Imagem Corporal; Insatisfação Corporal; Mulheres

\section{Resumen}

El objetivo de este estudio fue verificar la influencia de la presión de agentes socioculturales en la insatisfacción con el rostro y el cuerpo en mujeres jóvenes, mediadas por la internalización de un cuerpo esbelto y musculoso, así como para identificar la contribución de las características individuales a este modelo. Un total de 612 mujeres universitarias participaron en el estudio. Las estudiantes completaron las versiones en portugués Sociocultural Attitudes Towards Appearance Questionnaire-4 y del Body Area Scale-Revised y un cuestionario sociodemográfico. El modelo hipotético fue construido usando un modelado de ecuación estructural para probar la relación entre las variables. Se verificaron tanto el modelo ajustado, como la significancia de los recorridos hipotéticos. Los resultados proporcionan evidencias que cuanto mayor es la presión de los agentes socioculturales y la internalización de un cuerpo esbelto, mayor es la insatisfacción de las mujeres con la apariencia de su cuerpo y rostro. La media contribuyó a una mayor internalización del cuerpo musculoso, que redujo la insatisfacción con el cuerpo. La práctica de actividad física y un nivel económico más alto contribuyeron a una internalización más grande de un cuerpo musculoso, lo que redujo la insatisfacción con el cuerpo. Un nivel económico más alto también influenció en la internalización de un cuerpo esbelto e incrementó la insatisfacción con la cara y el cuerpo. Un mayor indice de masa corporal contribuyó a una mayor presión de los agentes socioculturales, y una mayor internalización de un cuerpo esbelto, así como una mayor insatisfacción con el cuerpo y la cara. Las relaciones identificadas en el modelo pueden contribuir al desarrollo de estrategias, con el objetivo de reducir la insatisfacción corporal y los desórdenes alimenticios en la población, tales como la aceptación corporal.

Imagen Corporal; Insatisfación Corporal;

Mujeres
Submitted on 27/Mar/2020

Final version resubmitted on 30/Jun/2020

Approved on 10/Aug/2020 